\title{
Original \\ Some historical notes on the research in corrosion of reinforcement
}

\section{Apuntes históricos sobre la investigación en corrosión de armaduras}

\author{
Carmen Andrade \\ International Center for Numerical Methods in Engineering, CIMNE, UPC, Spain
}

Received 20 December 2018; accepted 21 December 2018

Available online 22 January 2019

\begin{abstract}
A brief exercise is made on reporting some achievements in the history of reinforcement corrosion. It is a difficult task to try to summarize because there are numerous protagonists in the history then choices were made from a personal point of view. In the decade 1960-1970, reinforcement corrosion was a subject only of marginal interest because the number of built environment was limited. The use of electrochemical techniques was a milestone which enabled from the decade of the 1970 to study the effect of each variable with much more rigor. The studies on service life started in the decade of 1980, although they were not of general interest until next decade. From 1990 Rilem Committees and the Iberoamerican Program on Corrosion of CYTED extended the knowledge so widely that in the XXI century the subject attracts much research interest.
\end{abstract}

(C) 2018 Asociación Española de Ingeniería Estructural (ACHE). Published by Elsevier España, S.L.U. All rights reserved.

KEYWORDS: History; Corrosion; Electrochemistry; Service life; Codes of practice

\section{RESUMEN}

Se realiza un breve ejercicio para comunicar algunos logros en la historia de la corrosión de armaduras. Tratar de resumirlos es una tarea difícil ya que hay numerosos protagonistas en la historia, por lo que las elecciones se han hecho desde un punto de vista personal. En la década 1960-1970, la corrosión de armaduras solo era un tema de interés marginal porque el número de entorno construido era limitado. El uso de técnicas electroquímicas fue un hito que permitió, desde la década de 1970, estudiar el efecto de cada variable con mucho más rigor. Los estudios sobre la vida útil comenzaron en la década de 1980 aunque no fueron de interés general hasta la siguiente década. Desde 1990, los Comités de la RILEM y el Programa Iberoamericano sobre Corrosión de CYTED ampliaron el conocimiento tan ampliamente que en el siglo XXI el tema genera mucho interés en investigación.

() 2018 Asociación Española de Ingeniería Estructural (ACHE). Publicado por Elsevier España, S.L.U. Todos los derechos reservados.

PALABRAS ClaVE: Historia; Corrosión; Electroquímica; Vida útil; Códigos de prácticas

\section{1}

\section{INTRODUCTION}

I had the privilege of making a long journey of investigation on reinforcement corrosion and for that reason, also the responsibility of transmitting data and anecdotes that should be one stone with those of other. History is always polyhedral and has many interpretations. In present work I report some notes from a personal point of view. I am sorry for perhaps not being totally objective and not mentioning all the protag- onists and all the important contributions. I will try to extend present notes in the future trying to be more comprehensive. I would like that the present work is taken as a testimony of some visionaries who promoted these studies, supported them, or were outstanding contributors to the science and practice of concrete durability.

Corrosion by itself is a major problem in the industry due to the enormous economic consequences involved. There are constant data on direct costs for material loss, and indirect costs, for stopping and putting out of service industrial components or infrastructure. The economic consequences of cor-

E-mail address: candrade@cimne.upc.edu

https://doi.org/10.1016/j.hya.2018.12.002

0439-5689/@ 2018 Asociación Española de Ingeniería Estructural (ACHE). Published by Elsevier España, S.L.U. All rights reserved 
rosion and the need to mobilize the knowledge to avoid them, is one of the first issues that we explain to corrosion specialists and yet we are still not fully aware that it is necessary to intensify more preventive measures than corrective ones. In the field of concrete durability, there have been introduced very well preventive measures against the attack of the concrete itself, but there is still a long way to also efficiently prevent corrosion of the reinforcement.

Due to the numerous aspects that the corrosion of reinforcements involves, to make a summary of the historical evolution of the subject supposes a work of synthesis very remarkable. To try the challenge, it will be divided the history in decades paying much more attention to the initial times, less known at present. At initial times where the Polarization Resistance technique was proved to be a key tool in the study of the corrosion because it quantifies the phenomenon in a nondestructive manner and how this technique helps to predict the residual service life of a corroding structure. I beg the pardon for transmitting some personal anecdotes, that however is the time to report.

\section{2.}

\section{THE BEGINNINGS IN THE 1970S: DEVELOPMENT OF MEASUREMENT TECHNIQUES}

At present, we are visiting structures that were erected either ignoring the word durability or thinking that concrete was the material that would make steel eternal. It was not until the 70s that some awareness began to grow that the concrete could be porous allowing aggressive substances to penetrate through or could not counter the action of some admixtures currently used at that moment as the $\mathrm{CaCl}_{2}$. I joined the Eduardo Torroja Institute of Construction Sciences (IETcc) in June 1969, under the presentation of Enrique Costa Novella, Professor of Chemical Engineering at the Faculty of Madrid, to Prof José Calleja, the Head of the Department of Chemistry of the Institute. I was one of the selected students by Prof. Costa him tutor of my Doctorate. At that moment Prof. Calleja had already written an article [1] warning of the possible problem about the reinforcement corrosion because accelerator admixtures were a critical issue where still steam curing was not common, and then, calcium chloride was an accelerator of setting, especially interesting for prefabrication. Corrosion cases had started to be detected in some buildings having made use of the $\mathrm{CaCl}_{2}$ and Prof. Calleja offered to me that subject. The alternative subject that Prof. Calleja proposed to me to develop my thesis was the study of the optimal addition of gypsum to regulate the setting of cement. I joined the Institute in June 1969, just after finishing my degree in Chemical Industry but it was not until September that the selection of reinforcement corrosion as subject for my Master was made. The final reason was that I perceived a higher interest of Prof. Calleja on it. From my part, just the chapter of corrosion was the last one of the matter of Metallurgy that was neither reached nor explained during my studies. So I selected the topic that I knew anything about.

Declared to Prof. Calleja my total ignorance on the basis of the subject in the chosen topic, he suggested that I attended at the Faculty the matter of "Corrosion and Protection" that Sebastián Feliu had begun to teach in the specialty of Metallurgy, a specialty that I had not studied. These classes were essential to bring to fruition the work of the Master Thesis presented in June 1970. From the experimental testing works I will mention some anecdotes in order the reader could place the mind on the state of the knowledge at that time. Thus, I remember the emotion of Prof. Calleja when I showed him the bars removed from my first specimens with admixed $\mathrm{CaCl}_{2}$ and calcium formiate (Fig. 1): It is true that chloride corrodes!!! he said with great emphasis. That is to say, in 1970 they were the first results that in our country confirmed that calcium chloride should be banned as a setting accelerator. This corroborated result in the rest of the specimens (I manufactured 500 for the Master thesis) had two consequences:

- The protest and pressure on Prof. Calleja from the manufacturer of calcium chloride (Solvay) that were afraid to lose an application of enormous economic impact for them if $\mathrm{CaCl}_{2}$ was forbidden.

- The prohibition appeared in the version of the Spanish "Instruction of Calculation of Reinforced Concrete" of 1973, I deduced that after the proposal of Prof. Calleja. From then in Spain the use of calcium chloride added to the concrete mix proportions was forbidden. The amount in the mixing water should be lower than $0.4 \%$ referred to the cement weight.

In the Master Thesis [2] the period of testing was only of 3 months. In spite of being short, some specimens cracked as

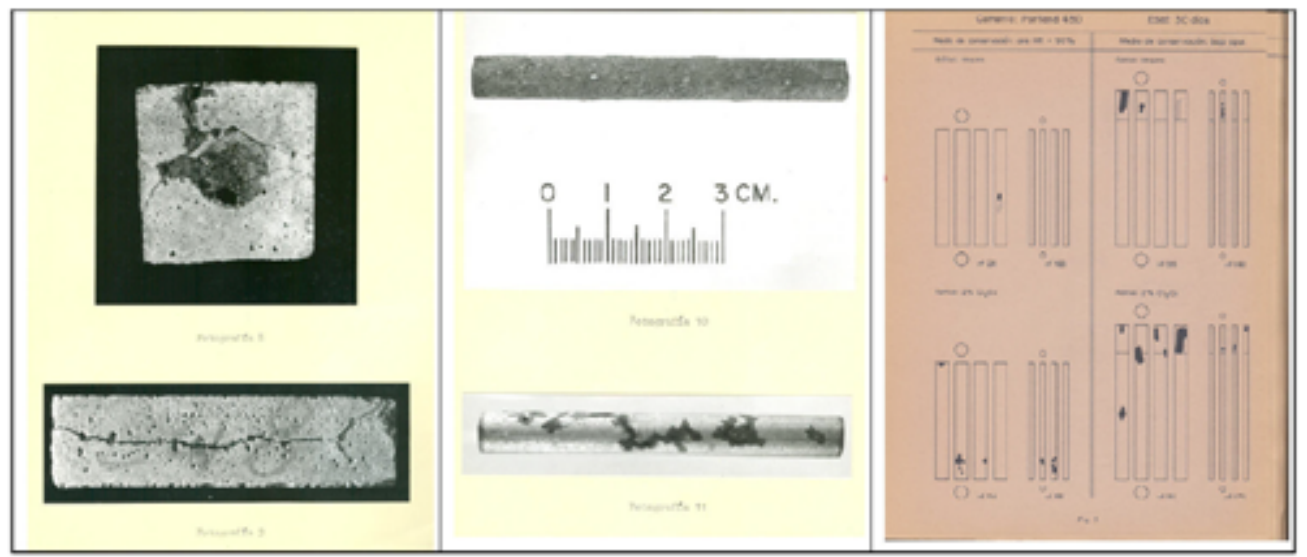

Figure 1. Left: specimens craked due to the corrosion induced by admixing $\mathrm{CaCl} 2$ after 3 months in high humidity. Center: aspect of some bars, upper totally corroded and down with localized corrosion, right: drowns of each specimen handmade to reproduce the corrosion pattern. 

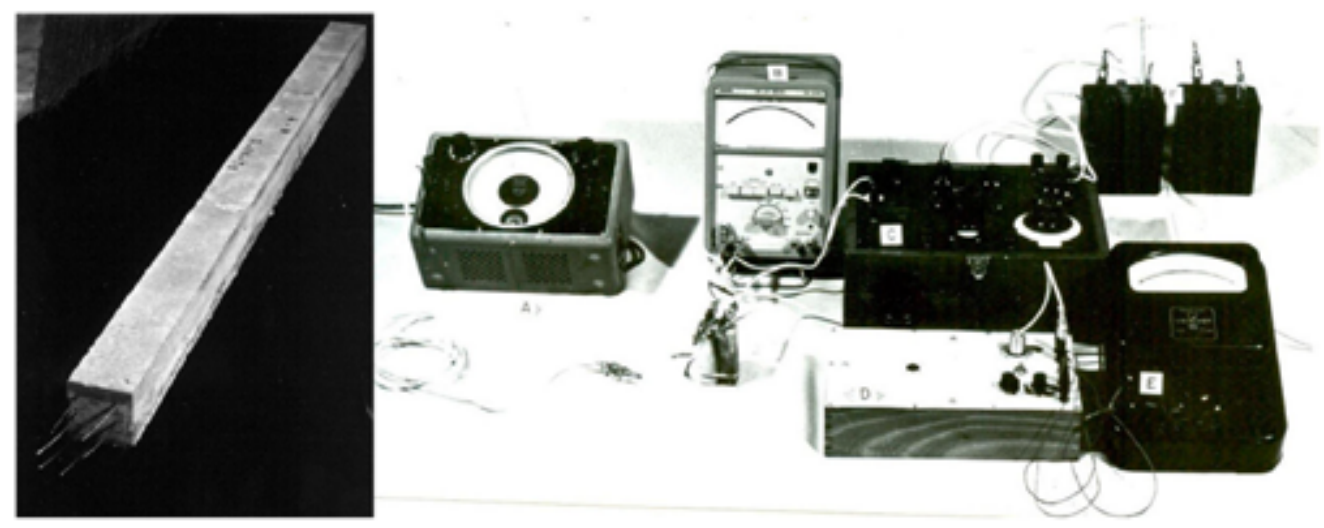

Figure 2. Left: prestressed beam manufactured for the work of the thesis. Right: set of equipments to measure the electrical resistance due to the concrete itself, multimeter for measuring the corrosion potential and in the right-down corner the galvanostat (white cover in the figure) and the black multimeter to measure the current.

shown in Fig. 1-left. In the right part of this figure is given the handmade drawn that I did for the 500 specimens because of the difficulty to make too many photographs. I had to reproduce by hand the pattern of the corrosion in each steel bar $(4$ sides of each bar).

I decided to continue with the Doctoral Thesis [3] on the same subject and go on to study inhibitors (nitrites, chromates and phosphates) that could compensate for the corrosive effect of chloride. The plan contemplated working with 12 different cements (those that were available then) and several inhibitors and concentrations. Given that I had manufactured 500 test pieces for the Master thesis, I raised the absolute need to develop a measurement technique that would save me having to break a test piece at each age. Prof. Feliu suggested the use of the Polarization Resistance technique, at that time a total novelty even at international level $[4,5]$. With the help of Prof. Feliu working not only at the University but also at the CENIM (National Center of Metallurgical Research) as Head of the Corrosion Department, and of José Antonio González researcher at CENIM and of José Fullea, a doctoral student, as me trying to apply the technique to the corrosion of lead in the sulfuric acid of car batteries. In my case it was the first time that that technique also named "Linear Polarization" was applied to concrete and that advance was immediately recognized when publishing in 1978 and 1980 in international journals with evaluators $[6,7]$. Since I was able to join the staff of the Institute in 1979, when shortly thereafter I requested to participate in a RILEM committee, all were congratulations and facilities, being in 1987 when the RILEM awarded me the Robert L'Hermite Medal to young researchers.

Fig. 2 shows, however, the precarious means that we then had for measuring. It shows a perspective of the beams $2 \mathrm{~m}$ long that I fabricated and the arrangement of equipment. The technique of the Polarization Resistance, $R_{\mathrm{p}}$, consists of applying a small electric current $(\Delta I)$ and measuring the change of potential $(\Delta E)$ that this disturbance produces in the reinforcement. The following formula had been previously proposed by Stern in 1957 [8] but not proved to be reliable and with several papers doubting of its applicability ( $B$ is a constant value which varies between 26 and 52 in the case of concrete):

$I_{\text {corr }}\left(\mu \mathrm{A} / \mathrm{cm}^{2}\right)=\frac{B}{R_{p}}=\frac{B}{(\Delta E / \Delta I) \text { area }}$

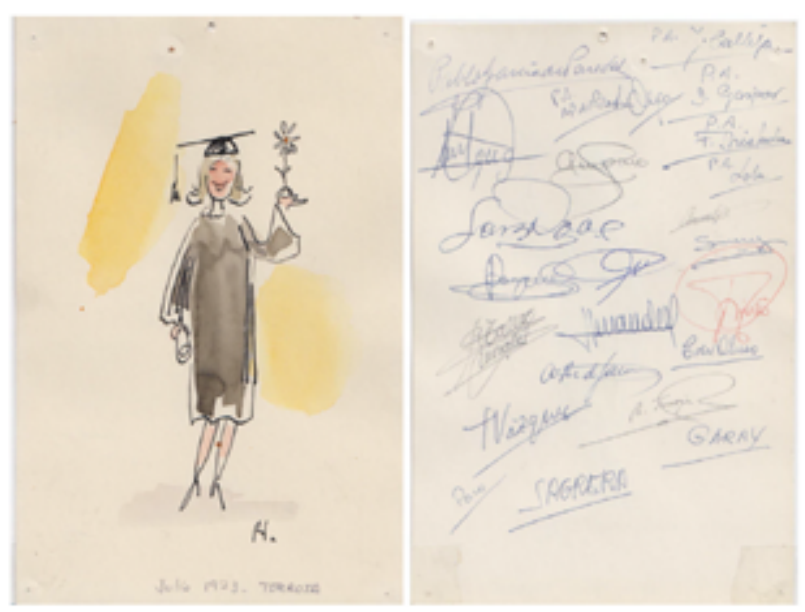

Figure 3. Gift for my doctoral Thesis of my colleagues painted by Bernard Petit.

José Maria Tobío, then Head of the Department of Physics of the Institute, made for me a "galvanostat" following the indications of CENIM technicians, inside a wooden box with yellow plastic cover (see Fig. 2). The problem that made me invest a whole year to solve it, was that the internal resistances of this device did not allow to apply a polarization small enough for the small size of my specimens $(2 \times 2 \times 8 \mathrm{~cm}$ with exposed surface around of $6 \mathrm{~cm}^{2}$ ). I went on to manufacture prestressed beams of $2 \mathrm{~m}$ (Fig. 2, left). They were 48 beams and with them I carried out the studies that allowed to establish the conditions to apply this technique to measure the corrosion rate of a steel embedded in concrete. Bases that have been irrefutable and valid until the present, since there is still no better technique than this to quantify the corrosion rate, not only in concrete, but in any metal/electrolyte system. I presented the thesis in July 1973 [3]. In Fig. 3 is given the gift signed by my colleagues of the Department of a drawn from Bernard Petit, then a draftsman at the Institute and then a famous painter of paintings with colored mortars.

As anecdotes of that period I find it seems to me interesting to rescue three:

- The first, deals with the fact that I was pregnant at the time of my first child, who was born a year before finishing the Thesis. The baby before and after birth was re- 

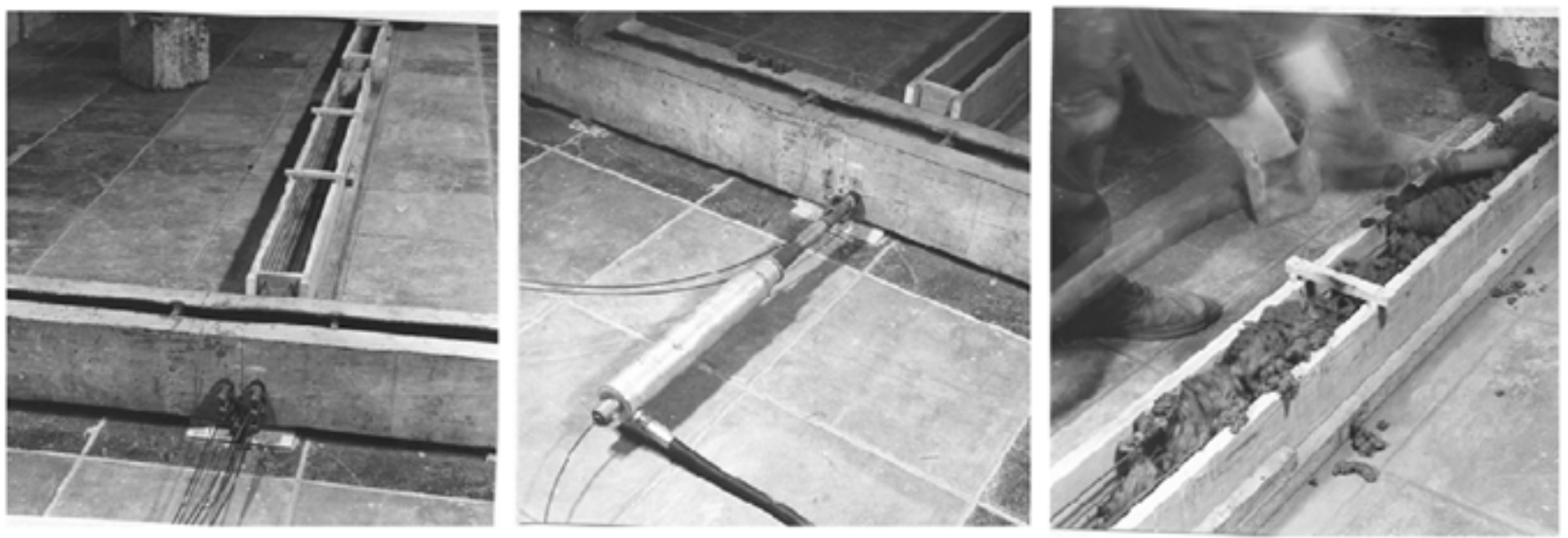

Figure 4. Prestressing arrangement for fabricating the 48 joists used fro the doctoral thesis.

ferred to as "Carmen's little thesis". At that time pregnant women stopped working and of course taking the baby to the nursery (from he was 3 months old during my writing of the thesis document) was greatly commented at work for good and bad.

- The second anecdote, was that the 48 beams first demanded much calculations and work at the structural laboratory for those who calculate and did the prestressing of the wires (never made before at the Institute (Fig. 4). Once fabricated the problem was that either occupy a large area or if stacked together their tremendous weight. Finally the beams were placed in the lab of the institute known as "the dungeons" since its floor was directly in the third basement on the ground and not on a floor. There, I locked myself for $7 \mathrm{~h}$ a day to measure with the galvanostat of the yellow plastic cover. Concentration was obligatory because nobody rarely came from those depths. I keep a great memory of that time of what happens to a prestressed beam when an electric current is applied to its wires. The several corrosion conditions of each beam were clearly differentiated through the results of the $R_{\mathrm{p}}$ values. Also during my Thesis studies I visited often the CENIM, where I had a place to work and access to all their equipment, a place I kept for a few years afterwards, in which I was even awarded a scholarship to study the corrosion resistance of galvanized reinforcements, until in 1979 year in which I joined the staff of the Institute of Construction Sciences.

- The third anecdote when I presented my thesis, was that Prof. Arredondo, then Director of the Institute, called me at his office to congratulate me and said solemnly: "You already know everything about corrosion, so you will have to go thinking in which new topic will work" My answer was confuse, something like "I do not think I know enough, I will need a lot of time to know something about this topic". I think today I would continue to answer in the same way.

\subsection{Stress corrosion cracking studies in Spain}

Simultaneously to the studies at the IETcc, the "Central Laboratory for Materials and Structures" of the Ministry of Public Affairs was also developing corrosion studies coordinated by Manuel Elices. They were made to find a solution for the colapses of prestressed pipes conducting the tap water to Madrid. Also guided by Prof. Calleja, I visited them very early in order to know each other and look for possible collaborations. These collaborations started one decade later when Elices moved to the Faculty of Civil Engineering to be Professor of Physics. More recently the group was one of the partners of the CONSOLIDER project together with CIMNE (Prof. Eugenio Oñate) and the IETcc. In that project was later incorporated the group of Prof. Gonzalo Ruiz of the University of Castilla La Mancha. This project enabled to consolidate a fruitful collaboration that still remains.

The group of Prof. Elices was almost always working in the area of the effect of tensions in the corrosion and the development of fracture mechanics theories. All the group has made remarkable contributions in the subject of materials science of metallic and nonmetallic materials [9-13].

In Fig. 5 is shown one of their contributions in which studied the stress concentration due to the existence of a crack with a semi-elliptic shape. Numerous other aspects have addressed by the group that have had international relevance awarding G. Guinea the RILEM Robert L'Hermite medal in 1994.

\subsection{Studies in other countries in the 70s until 1980}

Not many studies were active on the subject at the beginning of the 70s. In the Master Thesis I gathered everything I found tracing for hours in the library of the Institute and that of CENIM, and the number of citations that I got did not exceed 25. In the Thesis I found a bit more but not too many. I refer only few of them [14-20] because these remarkable works have already been completely forgotten. Also, I would like to name from those times other that should not be left unread so as not to repeat basic tests or question aspects that have been demonstrated since then [21-31].

Three problems can be identified that were studied at that time: corrosive effect of admixtures (among them calcium chloride), marine environments, and the corrosive effect of stray currents in the railways. The action of chlorides on hydration was studied in relation both to its mitigating effect of the sulfatic reaction in marine environments and its accelerating effect on the setting. It was outstanding the work of Hausmann [20], who establishes the critical relation of chlorides with respect to the $\mathrm{pH}$ of concrete at a value of $\mathrm{Cl} / \mathrm{OH}=0.6$, value that has remained valid until today. 


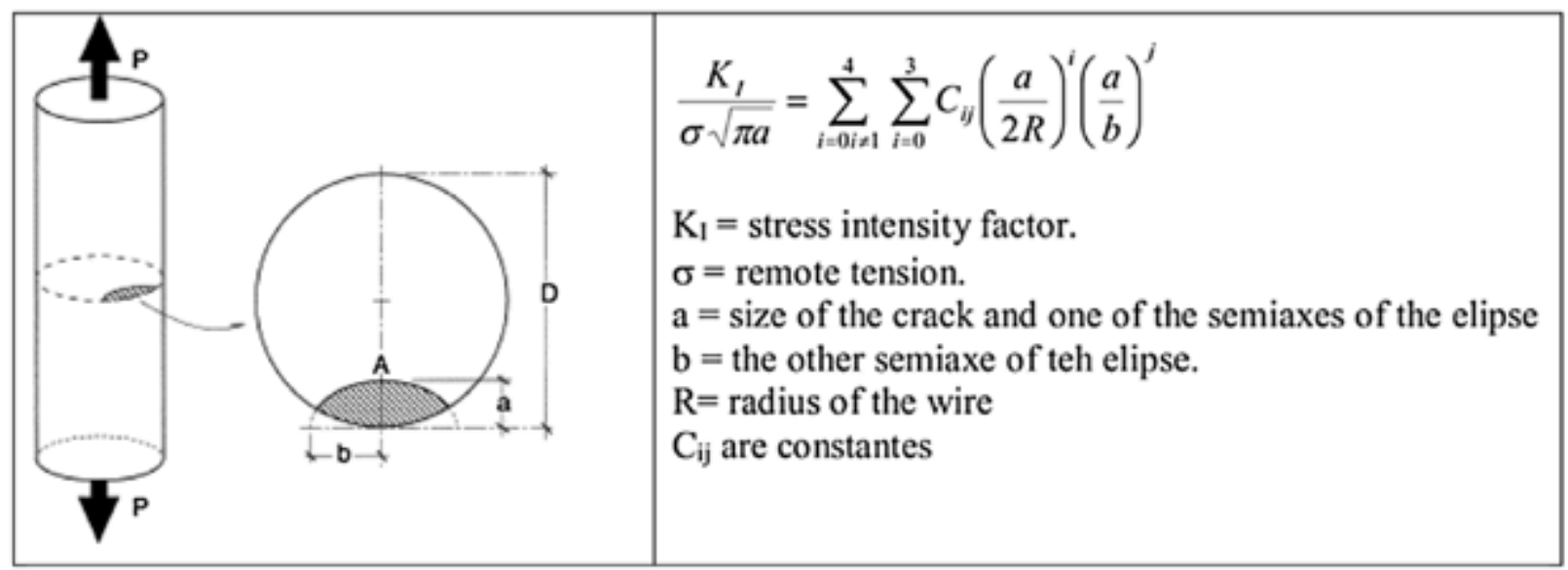

Figure 5. Stress intensity factor of the a semi-elliptic crack by the group of Prof. Elices [9-13].

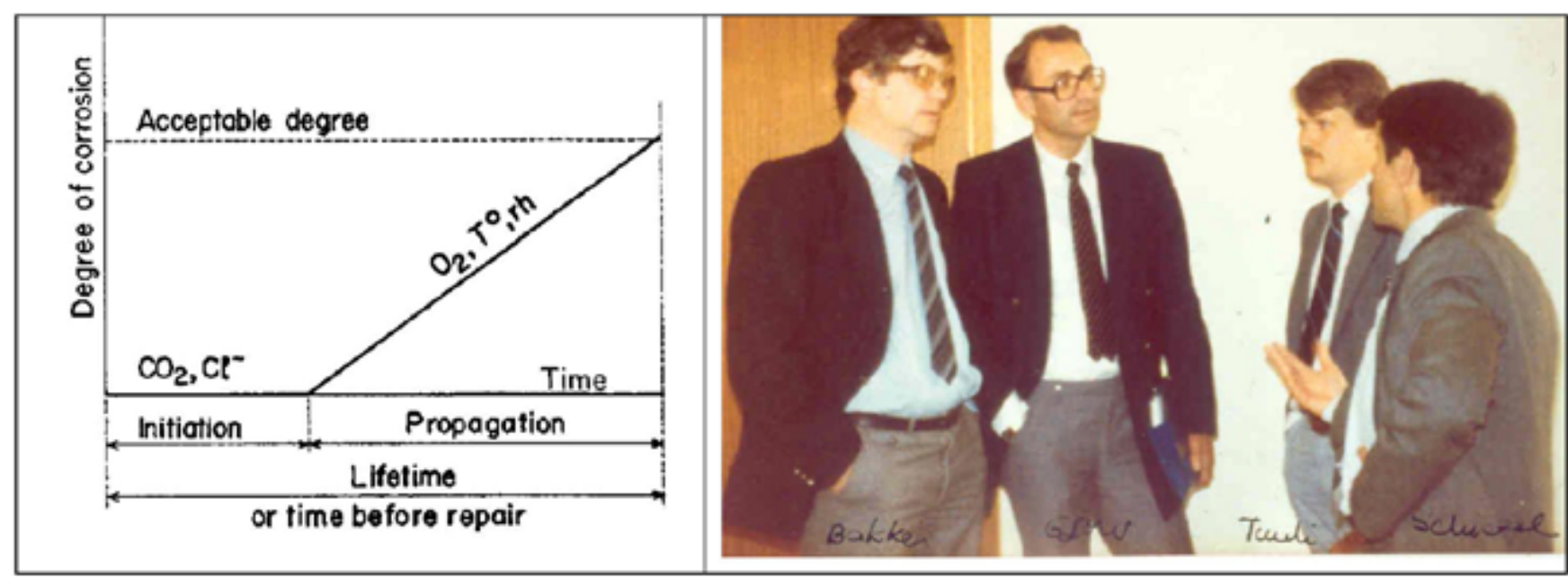

Figure 6. Left: diagram of service life in the thesis if K. Tuutti. Right: from the left to the right Rob Bakker (Holland), O. Gjorv (Norway), K. Tuutti (Sweden) and P. Schiessl (Germany) during a meeting of RILEM TC 60-Corrosion of Steel in concrete.

Also Gouda and Monfore [14] were working in the same subject and in parallel Cigna [21]. The techniques that they applied were of accelerated type, fundamentally curves of polarization and also potentiostatic tests as that proposed by Kaesche and Baümel $[16,17]$ later standardized by DIN and by CEN for the detection of corrosive substances in concrete. The publication of Page and Treadaway in Nature [21] supposed a disclosure of the problem in its basic aspects that contributed notably to the multiplication of congresses and publications.

3.

\section{DECADES OF 1980-2000: SERVICE LIFE AND CORROSION MECHANISMS}

The use of electrochemical techniques was a fundamental milestone that allowed, starting in 1970, to approach the studies with much more rigor on the effect of each variable. This is how the effects of carbonation [32] and the possible methods to avoid corrosion began to be studied, basically hot galvanizing [32], inhibitors [33], epoxy coatings for reinforcements [24] and cathodic protection [28].

It is nevertheless in the decade of 1980 when the calculation of service life was approached, that it was not object of general attention until the decade of 1990. Thus, K. Tuutti introduced the concept when he published his doctoral thesis [34] in 1982 with the diagram that is shown in Fig. 5 and that is extensively referred by all subsequent studies. Fig. 6 also shows K. Tuutti with Rob Bakker, Odd Gjorv and Peter Schiessl during a meeting of the Rilem Committee 60CSC "Corrosion of Steel in concrete" [35] chaired by Schiessl. Both this committee and the Workshops organized by Hans Arup of Force Institute in Denmark were important leaders of the work in the subject. For the sake of curiosity in Fig. 7 is given the group attending the first Workshop on Corrosion of Reinforcements in Copenhagen organized by Arup in 1981.

It has however to be mentioned that, although almost not cited, in 1979 Bazant [49-50] published two papers on the calculation of service life due to reinforcement corrosion. They were a milestone but inexplicably not very much used.

In Latinoamerican countries also the subject started to be studied in the decade of the 80s and the subsequent ones with great success due to the funds provided by the Program CYTED (Spanish Program on Cooperation for the Development) which enabled to establish several active Networks as they were "Durar" chaired by Oladis de Rincon from Venezuela [36], "Rehabilitar" chaired by Paulo Helene [37] from Brasil and "Prevenir" chaired by Pedro Castro [38] from Mexico. All of them with important original contributions in the subject. 


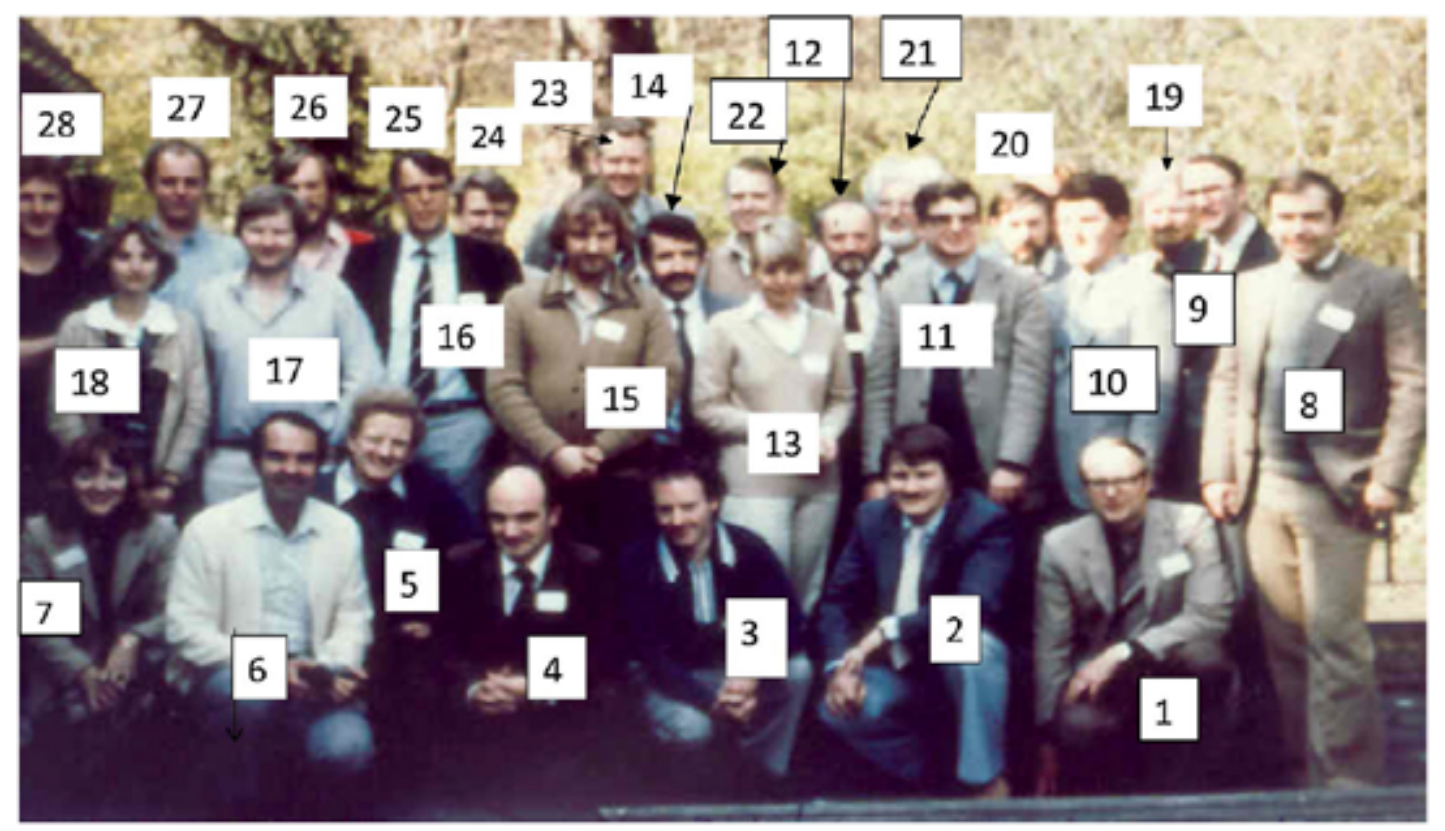

Figure 7. Participants in the workshop entitled 'Corrosion of steel in concrete' organized by Hans Arup at Copenhagen in 1981. In the first row from right to left: (2) K. Tuutti, (4) J.A. Gonzalez, (6) C. Locke, (7) C. Hansson, second row: (8) O. Vennesland, (9) O. Gjorv, (10) C. Page, (11) R.

Bakker, (12) J. Dawson, (13) Byfors, (14) P. Schiessl, (17) G. John, (18) C. Andrade, third row: (21) Wilkins, (22) H. Arup.
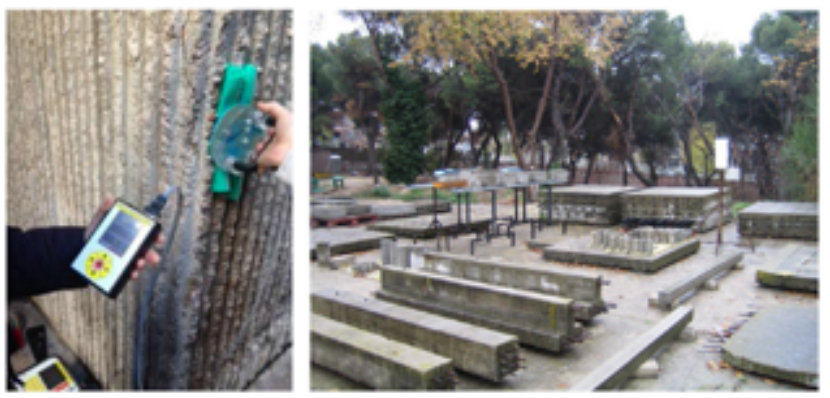

Figure 8. Left the corrosion rate meter in a column with rough finishing. Right: exposure site and the garden of the IETcc to study the effect of the climate into the corrosion of several concrete elements.

In the early 80s it was demonstrated the reliability of the Polarization Technique by calibrating its results with gravimetric tests made on the same bars using Faraday's law for the conversion of units. Thus, Fig. 7 shows the agreement of values from the electrochemical results and the gravimetric ones [6]. Only in the passive state when the corrosion is very small, is found a lack of agreement because the weight loss is not so accurate as can be the Linear Polarization technique.

During the 1990s, enormous advances were made in basic knowledge, among which the possibility of in situ measurement of the corrosion rate with the development of a portable corrosion-rate-meter (GECOR) (Fig. 7 right) made possible with the funds of a Eureka project and the company GEOCISA with the collaboration of Feliu and González from the CENIM. The device quantifies the corrosion rate of large structures through the confinement of the current that otherwise sprays out of the border of the auxiliary electrode to an unknown distance. If the area polarized by the current is unknown, the corrosion rate cannot be quantified. The corrosionratemeter confines the applied current and then the area is that below the probe of the equipment [39], Fig. 8. Figure 9 shows values of the instantaneous corrosion rate (Icorr) and its integration as "accumulated corrosion" (Pcorr).

In those years, RILEM established several committees, both on measurement techniques (TC154) [40-43], and on models based on the diffusion of chlorides and carbonation (TC178 and TC213). In this regard it is worth mentioning the contribution of $\mathrm{D}$. Whiting proposing in the 80 s to reduce the duration of the test of resistance to chlorides [25] by applying a potential difference to concrete. These works gave rise to an intense debate [44] that allowed to develop the theoretical basis for the diffusion of chlorides and their migration through electric fields, which have subsequently led to the profusion of numerical models on service life of concrete based in accelerated testing methods.

4. FROM 2000 TO THE PRESENT: MODELING AND
PROBABILISTIC TREATMENT. PREVENTION AND
REPAIR TECHNIQUES

The matters to remark in these almost two decades have being based in the work carried out in the CONTECVET project [45] in the decade of the 90s in which it is proposed how to calculate the residual structural capacity when the structures are corroded [47]. That is how to link the materials characteristics or models with the structural performance. Also a step forward in the decade of the 2000s has been the work in the European project DURACRETE [46] that has resulted in the incorporation of the Model Code 2010 [48] of fib of the probabilistic treatment of durability, in which the models of service life were fed with assumed values in order to create the framework of limit states theories.

Another area experimenting an important advance has been that related to preventive and repair methods. Researchers, engineers and companies have made a huge effort to give solutions for the growing number of structures that have had to be repaired. The companies have developed adhoc materials and techniques and the researchers have focused in giving 

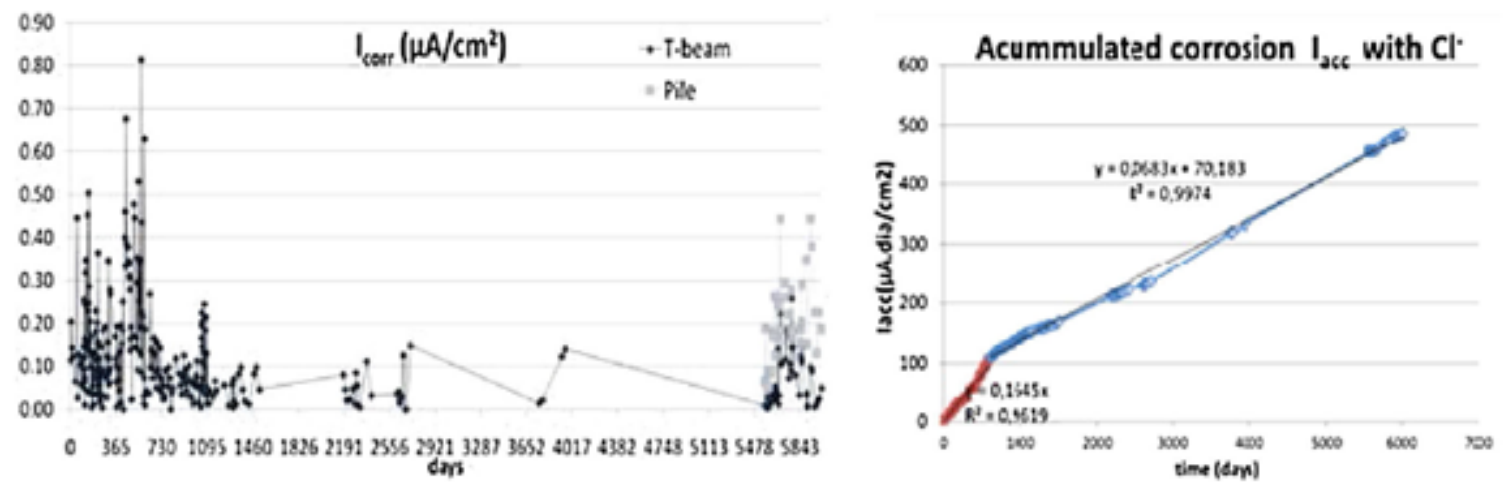

Figure 9. Variation of the corrosion rate of a beam of previous figure. Left instantaneous corrosion rate and right the accumulated corrosion calculated from the integration of the left curve at each time.

solutions and standards for the longer durability of concrete in aggressive environments. Particular effort has been made in Latinoamerica with the above mentioned Manuals from the Network DURAR [36], REHABILITAR [37] and PREVENIR [38]. Also in Latinoamerica is quite relevant role played by researchers as O. Rincon, P. Helene, P. Castro, E. Pazini, A. Nepumoceno and A. Torres Acosta and Alberto Sagúes in Tampa Florida. They have contributed to the understanding of:

- The impact of tropical climate on the reinforcement durability.

- The structural consequences of corrosion.

- Chlorides models or how epoxi-coated rebars corrode.

- The application of cathodic protection.

- Repair systems and techniques.

In spite of all efforts made until present however, in the 21 st century, the corrosion of the reinforcement is still one of the areas that constantly attracts research interest. There are many aspects to be clarified, especially in the effectiveness of repairs and in the calibration of the life models.

\section{Acknowledgements}

Numerous colleagues and students have been behind the work here summarized. My thanks to all of them. Particularly inspiring has been the work of members of Rilem committees, Latinoamerican Networks and at present, of fib Committees. Corrosion science progress is mainly based on their work.

\section{References}

[1] J. Calleja, Corrosion de armaduras en hormigones armados y pretensados (Reinforcement corrosión in reinforced and prestressed concretes) -Informes de la Construcción n ${ }^{\circ}$ 180, May 1966

[2] C. Andrade, Aportación a la corrosión de armaduras en el hormigón armado (Contribution to the corrosion of reinforcement in reinforced concrete), Master Thesis, University "Complutense" of Madrid, 1970.

[3] C. Andrade, New electrochemical technique for measurement of reinforcement corrosion in reinforced and prestressed concretes. Use of inhibitor admixtures as protection method, Doctoral Thesis, Complutense University of Madrid, June 1973.

[4] F. Mansfeld, K.B. Oldham, Modification of the Stern-Geary linear polarization equation Corrosion Science, vol. 11, Pergamon Press, 1971, pp. 787-796.

[5] M.E. Indig, C. Groot, Some limitationsof the linear polarization techniquesin evaluating corrosión behaviour, Corrosion (1969) 445.

[6] C. Andrade, J.A. Gónzalez, -Quantitative measurements of corrosion rate of reinforcing steels embedded in concrete using polarization resistance measurements-, Werkst. Korros. 29 (1978) 515
[7] J.A. González, S. Algaba, C. Andrade, Corrosion of reinforcing bars in carbonated concrete, Br. Corros. J. 3 (1980) 135-139.

[8] M. Stern, A method for determining corrosión rates from linear polarization data, Corrosion 14 (1958) 400

[9] M. Rosello, M. Elices, G.V. Guinea, Fracture of model concrete: 2. Fracture energy and characteristic length, Cem. Concr. Res. 36 (2006) 1345-1353.

[10] A. Valiente, M. Elices, Premature failure of prestressed steel bars Engineering Failure Analysis, vol. 5, no. 3, 1998, pp. 219-227.

[11] M.A. Astiz, An incompatible singular elastic element for two- and threedimensional crack problems, Int. J. Fract. 31 (1986) 105-124

[12] M. Elices, L. Caballero, A. Valiente, J. Ruiz, A. Martín, Hydrogen embrittlement of steels for prestressing concrete: the FIP and DIBt tests, Corrosion 64 (2) (2008) 164-174.

[13] M. Elices, A. Valiente, L. Caballero, M. Ioardaneschu, Fullea, J. SanchezMontero, V. Lopez, Failure analysis of prestressed anchor bars, Eng. Failure Anal. 24 (2012) 57-66A

[14] V.K. Gouda, G.E. Monfore, A rapid method for studying corrosion inhibiton of steel in concrete, J. PCA 3 (Septiembre 1965) 24.

[15] R.F. Stratfull, Effect of reinforced concrete in $\mathrm{ClNa}$ and $\mathrm{SO}_{4} \mathrm{Na}_{2}$ environments, Mater. Protect. Dic. (1964) 75.

[16] H. Kaesche, testing corrosion danger of steel reinforcement due to admixtures in concrete, Zement-Kalk-Gips 7 (1959) 289.

[17] A. Baumel, The effect of additives on the corrosion behaviour of steel in concerte, Zement-Kalk-Gips 7 (1959) 294.

[18] R. Cigna, M. Maraghini, G. Schippa, Effeto del contenuto di $\mathrm{Ca}_{2} \mathrm{Cl}$ sul cmportamento dei ferri affogati in malte cementizie, L'Industria italiana del Cemento Marzo (1966) 139.

[19] D.A. Hausmann, Electrochemical behaviour of steel in concrete, J. A.C.I Febr. (1964) 171

[20] D.A. Hausmann, A probability model for steel corrosion in concrete, Mater. Perform. 37 (10) (1996) 64-68.

[21] C.L. Page, K.W.J. Treadaway, Aspects of the electrochemistry of steel in concrete, Narute 297 (5862) (1982) 109-115.

[22] M. Collepardi, A. Marcialis, R. Turriziani, The Kinects of chloride ion penetration in concrete (in italian), Il Cemento 67 (1970) 157-164

[23] O. Gjorv, O. Vennesland, A. El-Susaidy, Mater. Perform. (1986) 39-44.

[24] A.A. Sagüés, R.G. Powers, R. Kessler, Corrosion Performance of EpoxyCoated Rebar in Florida Keys Bridges, CORROSION/2001, paper no. 01642, NACE International, Houston, TX, 2001.

[25] D. Whiting, "Rapid determination of the chloride permeability of concrete", in: Federal Highway Administration - Report FHWA/RD81/119, 1981 .

[26] N.S. Berke, A review of corrosion inhibitors, in: Environmental Treatment and Control, October, 1989, pp. 41-44.

[27] P. Bamforth, J. ChapmanAndrews, Long term performance of RC elements under U.K. coastal exposure conditions, in: N. Swamy (Ed.), International Conference on Corrosion and Corrosion Protection of Steel in Concrete, Sheffield Academic Press, 1994, pp. 139-156

[28] L. Lazzari, P. Pedeferri, Cathodic Protection - Polipress, Politecnico de Milano Publications, 2006.

[29] G.K. Glass, N.R. Buenfeld, The presentation of the chloride threshold level for corrosion of steel in concrete, Corros. Sci. 39 (5) (1997) 1001-1013. 
[30] J. Kropp., Relations between transport characteristics and durability, in: J Kropp, H.K. Hilsdorf (Eds.), Performance Criteria for Concrete Durability, E\&FN SPON, 1995, Results of Rilem TC 116.

[31] U. Nurnberger, Analysis and evaluation of failures in prestressed steel, in: Proceedings of the Third FIP Symposium, FIP-Berkeley, Wexham Springs, Slough, UK, 1981.

[32] A. Macías, C. Andrade, Corrosion rate of galvanized steel immersed in saturated solution of $\mathrm{Ca}(\mathrm{OH})_{2}$ in the $\mathrm{pH}$ range $12-13 \cdot 8, \mathrm{Br}$. Corros. J.(UK) 18 (2) (1983) 82-87

[33] C. Andrade, C. Alonso, J.A. González, Some laboratory experiments on the inhibitor effect of $\mathrm{NaNO}_{2}$ on reinforcement corrosion - cement, concrete, aggregates, ASTM 8 (2) (1986) 110-116.

[34] K. Tuutti, Corrosion of Steel in Concrete, $n^{\circ} 4-82$, Swedish Cement and Concrete Institute (CBI), Stockholm, 1982.

[35] P. Schiessl, Corrosion of steel in concrete, in: Report of RILEM TC 60CSC, Chapman and Hall, London, 1988.

[36] Manual DURAR Manual de Inspección, Evaluación y Diagnóstico de Corrosión en Estructuras de Hormigón Armado- O. de Rincón Editora. 2002.

[37] Manual REHABILITAR Manual de rehabilitacion de estructuras de hormigon reparacion refuerzo- Helene P. Pereira F. Editores 2003

[38] Manual PREVENIR. http://www.alconpat.org/contenido/libros.php.

[39] S. Feliú, J.A. González, S. Feliú Jr., C. Andrade, Confinement of the electrical signal or in-situ measurement of Polarization Resistance in Reinforced concrete, ACI Mater. J. 87 (1990) 457.

[40] B. Elsener, C. Andrade, J. Gulikers, R. Polder, M. Raupach, R ILEM TC 154EMC: Electrochemical Techniques for Measuring Metallic Corrosion Half-Cell Potential Measurements - Potential Mapping on Reinforced Concrete Structures, vol. 36, 2003, pp. 461-471.

[41] R. Polder, C. Andrade, B. Elsener, O. Vennesland, J. Gulikers, R. Weidert, M. Raupach, Test methods for onsite measurement of resistivity of concrete", RILEM TC 154EMC: electrochemical techniques for measuring metallic corrosion, Mater. Struct. 33 (2000) 603-611
[42] C. Andrade, C. Alonso, J. Gulikers, R. Polder, R. Cigna, Ø. Vennesland, M. Salta, A. Raharinaivo, B. Elsener, RILEM TC 154-EMC: Electrochemical Techniques for Measuring Metallic Corrosion Recommendations Test methods for on-site corrosion rate measurement of steel reinforcement in concrete by means of the polarization resistance method, Mater. Struct. 37 (273) (2004) 623-643.

[43] $\varnothing$. Vennesland, M. Raupach, C. Andrade, Recommendation of Rilem TC 154-EMC: "Electrochemical techniques for measuring corrosion in concrete - measurements with embedded probes, Mater. Struct. 40 (2007) $745-758$.

[44] C. Andrade, -Calculation of chloride diffusioncoefficients in concrete from ionic migration measurements, Cem. Concr. Res. 23 (3) (1993) $724-742$.

[45] CONTECVET - A Validated User's Manual for Assessing the Residual Life of Concrete Structures, DG Enterprise, CEC, 2001 (The manual can be downloaded from the web site of http://www.ietcc.csic.es/index.php/ es/publicaciones-2/manual-contecvet).

[46] DURACRETE. Probabilistic performance based on durability design of concrete structures. EU-Brite EuRam Project BE95-1347. A number of reports available from CUR Centre for Civil Engineering Research and Codes, Gouda, The Netherlands. 1999.

[47] J. Rodriguez, L.M. Ortega, J. Casal, Load carrying capacity of concrete structures with corroded reinforcement, in: M.C. Forde (Ed.), International Conference on Structural Faults \& Repairs, London, UK, vol. 2 , 1995, pp. 189-198.

[48] Model Code 2010. fib (2012).

[49] Z. P. Bazant Physical Model for steel corrosion in concrete sea structures. Theory and application. ASCE Journal of structural Division, June 1979ST6-p. 14551 (1138-1153)

[50] Z. P. Bazant Physical Model for steel corrosion in concrete sea structures. Application. ASCE Journal of structural Division, June 1979-ST6 p. 14552 (1156-1166). 